\title{
Announcement
}

\section{Change in Editorship}

The Publications Committee of the Psychonomic Society takes pleasure in announcing that N. John Castellan, Jr., has accepted the editorship of Behavior Research Methods, Instruments, \& Computers. His official 4-year term will begin after the present, and founding, editor, Joseph B. Sidowski, retires in 1990.

After August 1, 1989, manuscripts should be directed to N. John Castellan, Jr., at the Department of Psychology, Indiana University, Bloomington, Indiana 47405. 